Dicle Tıp Dergisi / Dicle Med J (2019) 46 (1) : 149 - 158

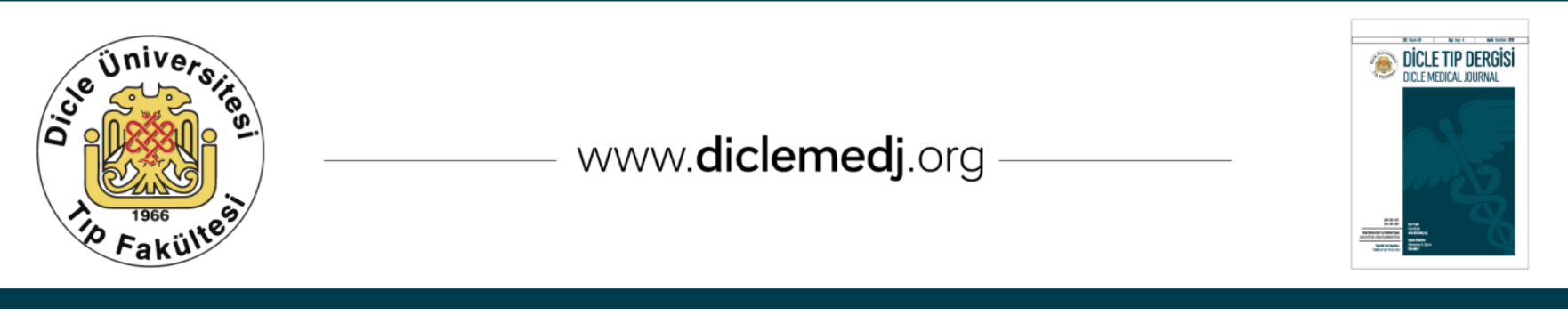

Özgün Araștırma / Original Article

\title{
Yenidoğan sepsisinde tam kan sayımı parametrelerinin tanısal değeri
}

\author{
Nurten Seringeç Akkeçeci' ${ }^{1}$ Büşra Seğmen², Sadık Yurttutan³ , Can Acıpayam4, \\ Zübeyde Dinçer ${ }^{5}$, Gözen Öksüz ${ }^{6}$
}

1 Kahramanmaraş Sütçü İmam Üniversitesi Tıp Fakültesi, Fizyoloji Anabilim Dall, Kahramanmaraș, Türkiye ORCID: 0000-0003-1915-2330

2 Kahramanmaraş Sütçü İmam Üniv. Tıp Fak., Çocuk Sağlığı ve Hastalıkları Anabilim Dalı, Kahramanmaraş, Türkiye ORCID: 0000-0002-5725-9131

3 Kahramanmaraş Sütçü Imam Üniv. Tıp Fak., Çocuk Sağlı̆ı ve Hastalıkları Anabilim Dalı, Kahramanmaraş, Türkiye ORCID: 0000-0002-4994-9124

4 Kahramanmaraş Sütçü İmam Üniv. Tıp Fak., Çocuk Sağlı̆̆ı ve Hastalıkları Anabilim Dalı, Kahramanmaraş, Türkiye 0RCID: 0000-0002-6379-224X

5 Kahramanmaraş Sütçü Imam Üniv. Tıp Fak., Çocuk Sağlı̆ı ve Hastalıkları Anabilim Dalı, Kahramanmaraş, Türkiye ORCID: 0000-0002-6549-2910

6 Kahramanmaraș Sütçü İmam Üniv. Tıp Fak., Anesteziyoloji ve Reanimasyon Anabilim Dalı, Kahramanmaraș, Türkiye ORCID: 0000-0001-5197-8031

Geliş: 07.12.2018; Revizyon: 05.02.2019; Kabul Tarihi: 12.02.2019

Öz

Amaç: Bu çalışma tam kan sayımı parametrelerinin ve tam kan sayımına dayalı skorların yenidoğan sepsisinde tanısal biyo-belirteç olarak kullanılıp kullanılamayacaklarını belirlemek amacıyla planlanmıştır.

Yöntemler: Retrospektif olarak planlanan bu çalıșmaya, yenidoğan sepsisi tanısı almış 70 hasta (Grup 1) ve hasta grubuyla benzer yaş, cinsiyet, doğum ağırlığı ve doğum haftasında olan 65 sağlıklı yenidoğan (Grup 2) olarak çalışmaya alındı. Demografik veriler, kan kültürü sonuçları, klinik ve laboratuvar bulguları tıbbi kayıtlardan elde edildi. Nötrofil/lenfosit oranı (NLO), trombosit/lenfosit oranı (TLO), eozinofil/lenfosit oranı (ELO), bazofil/lenfosit oranı (BLO) ve monosit/lenfosit oranı (MLO) gibi tam kan sayımına dayalı skorlar, sırasıyla nötrofil, trombosit, eozinofil, bazofil ve monosit sayısının lenfosit sayısına bölünmesiyle hesaplandı.

Bulgular: Yaş, cinsiyet, doğum tartısı, doğum şekli ve gebelik haftası gibi demografik özellikler bakımdan gruplar arasında fark yoktu $(p>0,05)$. C-reaktif protein düzeyi yenidoğan sepsisi grubunda anlamlı olarak yüksekti $(p<0,001)$. Yenidoğan sepsisi grubunda nötrofil sayısı anlamlı olarak yüksek iken $(\mathrm{p}<0,001)$, lenfosit, trombosit, eozinofil ve monosit sayıları anlamlı olarak düşük idi (sırasıyla; $p=0,001, p<0,001, p<0,001, p=0,005$ ). Hemoglobin, hematokrit, eritrosit, lökosit, bazofil, ortalama eritrosit hacmi (MCV), ortalama trombosit hacmi (MPV), eritrosit dağllım genişliği (RDW) ve trombosit dağılım genişliği (PDW), BLO, MLO ve TLO açısından gruplar arasında fark yoktu (p>0,05).

DOI: 10.5798/dicletip.534856

Yazışma Adresi / Correspondence: Nurten Seringeç Akkeçeci, Kahramanmaraş Sütçü Imam Üniversitesi Tıp Fakültesi, Fizyoloji Anabilim Dall, Bahçelievler Yerleşkesi 46100, Kahramanmaraş, Türkiye e-mail: seringec@hotmail.com 


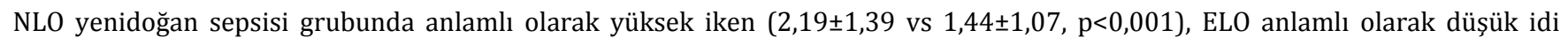
$(0,08 \pm 0,07$ vs $0,09 \pm 0,05, p=0,007)$. NLO CRP ile pozitif korelasyon gösterirken, ELO, lenfosit, trombosit, eozinofil ve monosit sayısı negatif korelasyon gösterdi $(\mathrm{p}<0,05)$. ROC curve analizi sonuçlarına göre CRP, NLO, ELO, nötrofil, lenfosit, trombosit, eozinofil ve monosit sayıları neonatal sepsis tanısı için anlamlı parametreler olarak saptandı. CRP için eşit değer 6,09 mg/L (duyarlılık \%88,6, özgüllük \%100, AUC:0,964, p<0,001), NLO için 1,01 (duyarlılık \%78,57, özgüllük \%63,08, AUC:0,727, p<0,001), ELO için 0,079 (duyarlılık \%64,29 özgüllük \%56,92, AUC:0,634, p=0,007), nötrofil sayısı için 4,66x109/L (duyarlılık \%68,57, özgüllük \%61,54, AUC:0,683, p<0,001), lenfosit sayısı için 4,33x109/L (duyarlılık \%65,71, özgüllük \%60,00, AUC:0,668, p=0,001), trombosit sayısı için 259,00x109/L (duyarlılık \%62,86, özgüllük \%58,46, AUC:0,659, p=0,001), eozinofil sayısı için 0,27x109/L (duyarlılık \%61,42, özgüllük \%69,23, AUC:0,708, p<0,001) ve monosit sayısı için 1,33x109/L (duyarlılık \%62,86, özgüllük \%56,92, AUC:0,647, $\mathrm{p}=0,003$ ) idi.

Sonuç: Duyarlılık ve özgüllükleri CRP'den düșük olmasına rağmen; NLO, ELO, nötrofil, lenfosit, trombosit, eozinofil ve monosit sayıları yenidoğan sepsisi tanısına katkıda bulunan yardımcı veriler olarak kabul edilebilir. Özellikle, NLO en yüksek duyarlılık ve özgüllük ile neonatal sepsis tanısında en yararlı tam kan sayımı parametresi gibi görünmektedir.

Anahtar kelimeler: Yenidoğan sepsisi, nötrofil/lenfosit oranı, eozinofil/lenfosit oranı, trombosit sayısı, eozinofil sayısı.

\title{
Diagnostic value of complete blood count parameters in neonatal sepsis
}

\begin{abstract}
Objective: This study was planned to determine whether complete blood count parameters and scores based on complete blood count can be used as a diagnostic marker in neonatal sepsis.

Methods: This retrospective study included 70 patients with neonatal sepsis (Group 1) and 65 healthy neonates (Group 2) with similar age, sex, birth weight, and gestational age. The demographic data, blood culture results, clinical and laboratory findings were obtained from the medical records. Scores based on complete blood count such as neutrophil-to-lymphocyte ratio (NLR), platelet-to-lymphocyte ratio (PLR), eosinophil-to-lymphocyte ratio (ELR), basophil-to-lymphocyte ratio (BLR) and monocyte-to-lymphocyte ratio (MLR) were calculated by dividing the number of neutrophils, platelets, eosinophils, basophils and monocytes by the number of lymphocytes, respectively.

Results: There were no significant differences between the groups in terms of demographic characteristics such as age, gender, birth weight, type of delivery and gestational week. C-reactive protein level was significantly higher in the neonatal sepsis group ( $p<0.001)$. While neutrophil count was significantly higher $(p<0.001)$, lymphocyte, platelet, eosinophil and monocyte counts were significantly lower $(p=0.001, p<0.001, p<0.001, p=0.005$, respectively) in neonatal sepsis group. Hemoglobin, hematocrit, erythrocyte, leukocyte, basophil, mean corpuscular volume (MCV), mean platelet volume (MPV), erythrocyte distribution width (RDW) and platelet distribution width (PDW), BLR, MLR, and PLR were not found different between groups $(p>0.05)$. While NLR was significantly higher $(2.19 \pm 1.39$ vs $1.44 \pm 1.07, \mathrm{p}<0.001)$, ELR was significantly lower $(0.08 \pm 0.07$ vs $0.09 \pm 0.05, \mathrm{p}=0.007)$ in neonatal sepsis group. NLR was positively correlated while ELR, lymphocyte, platelet, eosinophil and monocyte counts were negatively correlated with CRP $(\mathrm{p}<0.05)$. According to the results of ROC curve analysis, CRP, NLR, ELR, neutrophil, lymphocyte, platelet, eosinophil and monocyte counts were significant parameters for the diagnosis of neonatal sepsis. Cut-off values were $6.09 \mathrm{mg} / \mathrm{L}$ for CRP (sensitivity 88.57\%, specificity 100\%, AUC: $0.964, \mathrm{p}<0.001$ ), 1.01 for NLR (sensitivity 78.57\%, specificity 63.08\%, AUC: $0.727, \mathrm{p}<0.001,0.079$ for ELR (sensitivity $64.29 \%$, specificity $56.92 \%$, AUC: $0.634, \mathrm{p}=$ 0.007), 4.66x109/L for neutrophil count (sensitivity 68.57\%, specificity $61.54 \%$, AUC: $0.683, \mathrm{p}<0.001$ ), $4.33 \times 109 / \mathrm{L}$ for lymphocyte count (sensitivity $65.71 \%$, specificity $60.00 \%$, AUC: $0.668, \mathrm{p}=0.001$ ), $259.00 \times 109 / \mathrm{L}$ for platelet count (sensitivity $62.86 \%$, specificity $58.46 \%$, AUC: $0.659, \mathrm{p}=0.001$ ), $0.27 \times 109 / \mathrm{L}$ for neutrophil count (sensitivity $61.42 \%$, specificity $69.23 \%$, AUC: $0.708, \mathrm{p}<0.001$ ) and $1.33 \times 109 / \mathrm{L}$ for monocyte count (sensitivity $62.86 \%$, specificity $56.92 \%$, AUC: $0.647, \mathrm{p}=0.003$ )

Conclusion: Although their sensitivities and specificities lower than CRP; NLR, ELR, neutrophil, lymphocyte, platelet, eosinophil and monocyte counts can be accepted as adjunctive data that contribute to the diagnosis of neonatal sepsis. In particular, NLR seems to be the most useful complete blood count parameter in the diagnosis of neonatal sepsis with the highest sensitivity and specificity.
\end{abstract}

Keywords: Neonatal sepsis, neutrophil-to-lymphocyte ratio, eosinophil-to-lymphocyte ratio, platelet count, eosinophil count. 


\section{GİRIS}

Yenidoğan sepsisi, yaşamın ilk ayında kanıtlanmış veya şüpheli enfeksiyon sonucu gelişen sistematik inflamatuar yanıt olarak tanımlanmaktadır ${ }^{1}$. Yenidoğan sepsisi, tanı ve tedavisindeki gelişmelere rağmen neonatal dönemde önemli bir mortalite ve morbidite nedenidir. Yenidoğan sepsisi bulguların ortaya çıkış zamanına göre erken başlangıçlı sepsis ve geç başlangıçlı sepsis olmak üzere iki gruba ayrılmıştır. Erken başlangıçlı sepsis yaşamın ilk haftasından önce (bazı çalışmalarda ilk 72 saat olarak belirtilmiştir), geç başlangıçlı sepsis ise yaşamın ilk haftasından sonra gelişir² ${ }^{2}$.

Yenidoğan sepsisinde klinik bulguların hastalığa özgü olmaması nedeniyle karşılașılan en büyük zorluklardan biri doğru tanı koymaktır. Yardımcı laboratuvar testlerinin tek başına ya da bir arada kullanılması yeterli duyarlılık ve özgüllüğe sahip değildir. Yenidoğan sepsisi tanısında altın standart kan kültüründe üreme olmasıdır, ancak pozitiflik oranı düşüktür ${ }^{3}$. Ayrıca kan kültürü sonucunun negatif olması yenidoğan sepsisi tanısını ekarte ettirmez ${ }^{4}$. Yenidoğan sepsisi tanısı için kan kültürü, klinik ve laboratuvar bulgularının birlikte değerlendirilmesi gereklidir 5 .

Yenidoğan sepsisinin erken tanısı için değerlendirilen sayısız biyo-belirteç olmasına rağmen bugüne kadar ideal bir biyo-belirteç olmak için gerekli tüm kriterleri karşılayan, yüksek duyarlılık, özgüllük, pozitif prediktif değer (PPV) ve negatif prediktif değeri (NPV) olan ideal bir biyo-belirteç saptanmamıștır. En sık kullanılan biyo-belirteçler C-reaktif protein (CRP) ve prokalsitonindir (PCT), ancak her ikisi de farklı çalışmalarda çeşitli duyarlılık, özgüllük, PPV ve NPV göstermiştir6.

Tam kan sayımı, evrensel olarak kullanılan, çeșitli hastalıklar için önemli takip parametreleri içeren ve karar aşamasında hekime yardımcı olan hızlı ve ucuz bir testtir ${ }^{7}$. Tam kan sayımı parametrelerinden olan lökosit sayısı, nötrofil sayısı ve trombosit sayısı yenidoğan sepsisi tanısında yaygın olarak kullanılan laboratuvar parametreleridir ${ }^{8}$. Son yıllarda, tam kan sayımı parametrelerinden olan ortalama trombosit hacmi (MPV) 9,10 , trombosit dağılım genişliği (PDW) 9,10 , eozinofil sayısı ${ }^{11}$, eritrosit eritrosit dağılım genişliğ i (RDW) ${ }^{12}$ ve tam kan sayımına dayalı skorlardan olan nötrofil/lenfosit oranı (NLO)1,11,13,14 ve trombosit/lenfosit oranı (TLO) ${ }^{1,13}$ değerleri yenidoğan sepsisi tanısının potansiyel biyobelirteçleri olarak araştırılmıştır. Bununla birlikte, yapılan az sayıdaki bu çalışmalarda bu biyo-belirteçlerin tanısal değerine ilişkin sonuçlar çelişkili görünmektedir ${ }^{1,11,13,14}$ Literatürde tam kan sayımına dayalı diğer skorları (eozinofil/lenfosit oranı (ELO), bazofil/lenfosit oranı (BLO), monosit/lenfosit oranı (MLO)) inceleyen ya da tam kan sayımı parametrelerinin hepsini ve bu parametrelere dayalı skorları bir arada inceleyen herhangi bir çalıșmaya rastlanmamıștır.

$\mathrm{Bu}$ çalışma tam kan sayımı parametrelerinin ve tam kan sayımına dayalı skorların yenidoğan sepsisisinde tanısal biyobelirteç olarak kullanılıp kullanılamayacaklarını belirlemek amacıyla yapıldı.

\section{YÖNTEMLER}

Bu retrospektif çalışmaya, Mart 2016 ile Kasım 2017 tarihleri arasında Kahramanmaraş Sütçü İmam Üniversitesi Tıp Fakültesi Sağllk Uyguluma ve Araştırma Hastanesi Çocuk Sağlı̆̆ ve Hastalıkları Yenidoğan Yoğun Bakım Ünitesi'nde yatan ve klinik ve laboratuar bulgularıyla erken ya da geç başlangıçlı yenidoğan sepsisi tanısı almış 70 hasta (Grup 1) ve hastanemize rutin kontrol için başvurmuş olan hasta grubuyla benzer yaş, cinsiyet ve doğum haftasında olan herhangi bir akut ya da kronik infeksiyonu ve herhangi bir akut ya da kronik hastalığı bulunmayan 65 sağlıklı yenidoğan (Grup 2) olarak çalışmaya alındı. Hayatının ilk yedi gününde sepsis tanısı almış 
olan olgular erken başlangıçlı sepsis (31 hasta), yedinci gün ve sonrasinda sepsis tanısı alan olgular ise geç başlangıçlı sepsis (39 hasta) olarak kabul edildi. Yenidoğan sepsisi tanısı kan kültürü, klinik ve laboratuvar bulgularının birlikte değerlendirilmesi ile konuldu. Kan kültüründe üreme olan olgular kanıtlanmış sepsis, (20 hasta) kan kültüründe üreme olmayan olgular klinik sepsis (50 hasta) olarak değerlendirildi. Klinik sepsis olgularında aşağıdaki 6 klinik bulgudan en az ikisinde ve 6 laboratuvar bulgusundan en az ikisinde pozitiflik görülmekteydi: a) Klinik bulgular: 1$)$ kardiyovasküler değişiklikler (hipotansiyon, ritm düzensizliği, bradikardi, taşikardi) 2) solunumsal değişiklikler (apne, taşipne, akut solunum sıkıntısı) 3) non-spesifik değişiklikler (irritabilite, hipotoni, laterji) 4) gastrointestinal değişiklikler (beslenme intoleransı, abdominal distansiyon, emmede azalma) 5) ISI değişiklikleri (hipotermi $<36^{\circ} \mathrm{C}$, hipertermi $>38,5 \stackrel{\circ}{ } \mathrm{C}$, ısı düzensizliği) 6) Cilt ve cilt altı lezyonlar (peteşiyel döküntü, sklerem). Laboratuvar bulguları: 1) Lökosit sayısı (lökopeni $=$ lökosit sayısının $<5,000 / \mathrm{mm}^{3}$ olması veya lökositoz= lökosit sayısının $>20,000 / \mathrm{mm}^{3}$ olması 2) Trombosit sayısı (trombositopeni=trombosit sayısinin $<150,000 / \mathrm{mm}^{3}$ olması) 3) İmmatur/ total nötrofil oranı (I/T) $\geq 0,2$ 4) CRP $>10 \mathrm{mg} / \mathrm{L} \mathrm{5)}$ Kan şekeri izlemi (hipoglisemi, hiperglisemi) 6) Metabolik asidoz (Baz açığ $<10 \mathrm{mEq} / \mathrm{L}$ ) 1,13,15.

Tanı konmuş pnömoni veya diğer inflamatuvar durumları, CNS malformasyonları, metabolik bozuklukları, kromozom anomalileri, intrauterin büyüme kısıtlaması veya doğum asfiksisi bulunan yenidoğanlar çalışma dişı birakıldı.

Olguların demografik verileri (cinsiyet, yaş, sepsis başlangıç zamanı, doğum şekli, doğum haftası, doğum ağırlı̆̆ı), kan kültürü sonuçları, klinik ve laboratuvar bulguları (CRP ve tam kan sayımı parametreleri) dosya kayıtlarından elde edildi. NLO, TLO, ELO, BLO, MLO gibi tam kan sayımına dayalı skorlar, sırasıyla nötrofil, trombosit, eozinofil, bazofil ve monosit sayısının lenfosit sayısına bölünmesiyle hesaplandı.

Çalışmaya başlamadan önce KSÜ Tıp Fakültesi Klinik Araştırmalar Etik Kurulu'ndan onay alındı (2017/20: Karar No: 06).

Tüm istatistiksel analizler "Windows için SPSS 15.0" kullanılarak yapıldı. Verilerin normal dağılıma uygunluğu ve varyansların homojenliği ve sirasiyla Kolmogorov-Smirnov testi ve Levene testi kullanılarak değerlendirildi. Verilerin normal dağılması ve varyanslarının homojen olması halinde, gruplar arasındaki fark Bağımsız Örneklemler için TTesti ile, aksi halde Mann-Whitney U Testi ile belirlendi. Sayısal veriler ortalama \pm standart sapma olarak, kategorik değişkenler ise sayı ve yüzde olarak gösterildi. Yenidoğan sepsisi tanısinda CRP, NLO, ELO, nötrofil, lenfosit, trombosit, eozinofil ve monosit sayılarının eşit (cut-off) değerleri, duyarlılık ve özgüllükleri ROC (Receiver-operating characteristic) analizi ile belirlendi. Test sonuçları $\mathrm{p}<0.05$ ise istatistiksel olarak anlamlı kabul edildi.

\section{BULGULAR}

Grup 1'de 70, Grup 2'de 65 olmak üzere çalışmamıza toplam 135 yenidoğan dahil edildi. Yenidoğan sepsisli olguların 31'i $(\% 44,3)$ erken başlangıçlı yenidoğan sepsisi, 39'u (\%55,7) geç başlangıçlı yenidoğan sepsisi idi. Sepsisli yenidoğanların 20 'sinde $(\% 28,6)$ kanıtlanmış sepsis, 50'sinde $(\% 71,4)$ klinik sepsis saptandı. Kan kültüründe en fazla metisiline dirençli Staphylococcus epidermidis (MRSE) (5 hastada) üremesi oldu. 3 hastada Enterococcus faecalis, ikişer hastada Klebsiella pneumoniae, metisiline duyarlı Staphylococcus epidermidis (MSSE) ve birer hastada Acinetobacter baumani, Staphylococcus aureus, Enterobacter cloacae, metisiline dirençli Staphylococcus capitis, Klebsiella oxytaca, alfa hemolitik streptococcus ve Candida kefyr üredi. Sepsisli yenidoğanların 3'ünde $(\% 4,3)$ kardiyovasküler, 22 'sinde $(\% 31,4)$ solunumsal, 5'inde $(\% 7,1)$ 
non-spesifik, 34'ünde $(\% 48,6)$ gastrointestinal, 1'inde $(\% 1,4)$ ısı, 5 'inde $(\% 7,1)$ ciltte değișikler saptandı. Sepsisli yenidoğanların 2'sinde $(\% 2,9)$ lökopeni, 13'ünde lökositoz $(\% 18,6)$, 22'sinde trombositopeni (\%31,4), 11'inde $(\% 15,7) \quad \mathrm{I} / \mathrm{T} \quad 20,2, \quad 61$ 'inde $(\% 87,1) \quad$ CRP yüksekliği, 1'inde $(\% 1,4)$ hipoglisemi ve 2 'sinde $(\% 2,9)$ asidoz tespit edildi.

Tablo 1: Gruplara ait demografik özellikler.

\begin{tabular}{|l|c|c|c|}
\hline & Grup 1(70) & Grup 2(65) & $\mathrm{p}$ \\
\hline Yaş & $15,36 \pm 19,87$ & $15,51 \pm 19,41$ & 0,688 \\
\hline $\begin{array}{l}\text { Yaş n (\%) } \\
<7 \\
\geq 7\end{array}$ & $31(44,3)$ & $30(46,2)$ & 0,267 \\
\hline $\begin{array}{l}\text { Cinsiyet n (\%) } \\
\text { Erkek } \\
\text { Kız }\end{array}$ & $39(55,7)$ & $35(53,8)$ & \\
\hline Doğum tartısı (kg) & $2182,86 \pm 1104,85$ & $2026,77 \pm 960,82$ & $0,545^{*}$ \\
\hline Gebelik haftası & $33,53 \pm 4,88$ & $33,61 \pm 4,11$ & $0,982^{*}$ \\
\hline Doğum şekli n(\%) & $50(61,5)$ & 0,875 \\
Sezeryan & $59(84,3)$ & $54(83,1)$ & 0,849 \\
Normal doğum & $11(15,7)$ & $11(16,9)$ & \\
\hline
\end{tabular}

Ki-Kare Testi, * Mann-Whitney U Testi

Hasta (Grup 1) ve sağlıklı yenidoğanlara (Grup 2) ait demografik özellikler Tablo 1'de verilmiştir. Yaş, cinsiyet dağılımı, doğum tartısı, doğum şekli ve gebelik haftası gibi demografik özellikler bakımdan gruplar arasında fark yoktu ( $>0,05$; Tablo 1). Yenidoğan sepsisli hastaların 44'ü $(\% 62,9)$ erkek, 26'sı $(\% 37,1)$ kızdı. Yenidoğan sepsisi grubunda E/K oranı 1,69 idi.

Tablo 2: Gruplara ait laboratuvar bulguları.

\begin{tabular}{|l|l|l|l|}
\hline & Grup 1 (70) & Grup 2 (65) & $\mathrm{p}$ \\
\hline CRP (mg/L) & $51,28 \pm 60,41$ & $3,16 \pm 0,47$ & $<0,001^{*}$ \\
\hline Hematokrit (\%) & $41,14 \pm 12,39$ & $44,31 \pm 10,19$ & 0,108 \\
\hline Hemoglobin(g/dL) & $13,98 \pm 4,94$ & $14,85 \pm 3,66$ & 0,249 \\
\hline Eritrosit $\left(10^{12} / \mathrm{L}\right)$ & $4,11 \pm 0,99$ & $4,29 \pm 0,93$ & $0,228^{*}$ \\
\hline Lökosit $\left(10^{9} / \mathrm{L}\right)$ & $14,08 \pm 8,18$ & $12,74 \pm 5,33$ & 0,268 \\
\hline Nötrofil $\left(10^{9} / \mathrm{L}\right)$ & $7,24 \pm 4,26$ & $5,13 \pm 4,41$ & $<0,001^{*}$ \\
\hline Lenfosit $\left(10^{9} / \mathrm{L}\right)$ & $3,80 \pm 1,59$ & $4,81 \pm 1,77$ & 0,001 \\
\hline Trombosit $\left(10^{9} / \mathrm{L}\right)$ & $235,73 \pm 144,63$ & $303,23 \pm 115,62$ & $0,001^{*}$ \\
\hline
\end{tabular}

\begin{tabular}{|l|l|l|l|}
\hline Eozinofil $\left(10^{9} / \mathrm{L}\right)$ & $0,28 \pm 0,25$ & $0,43 \pm 0,23$ & $<0,001^{*}$ \\
\hline Monosit $\left(10^{9} / \mathrm{L}\right)$ & $1,15 \pm 0,71$ & $1,49 \pm 0,64$ & 0,005 \\
\hline Bazofil $\left(10^{9} / \mathrm{L}\right)$ & $0,08 \pm 0,06$ & $0,10 \pm 0,07$ & 0,567 \\
\hline MCV (fL) & $102,31 \pm 11,86$ & $102,94 \pm 8,99$ & 0,727 \\
\hline RDW (\%) & $17,35 \pm 1,87$ & $21,31 \pm 1,79$ & $0,954^{*}$ \\
\hline PDW (fL) & $13,6 \pm 4,9$ & $13,3 \pm 4,5$ & $0,924^{*}$ \\
\hline MPV (fL) & $10,45 \pm 2,09$ & $10,35 \pm 0,85$ & 0,185 \\
\hline ELO & $0,08 \pm 0,07$ & $0,09 \pm 0,05$ & $0,007^{*}$ \\
\hline BLO & $0,02 \pm 0,01$ & $0,03 \pm 0,01$ & $0,326^{*}$ \\
\hline MLO & $0,33 \pm 0,22$ & $0,38 \pm 0,31$ & $0,560^{*}$ \\
\hline TLO & $61,66 \pm 37,52$ & $68,39 \pm 30,06$ & $0,182^{*}$ \\
\hline NLO & $2,19 \pm 1,39$ & $1,44 \pm 1,07$ & $<0,001^{*}$ \\
\hline
\end{tabular}

CRP; C-Reaktif Protein, MCV; ortalama eritrosit hacmi, RDW; eritrosit dağılım genişliği, PDW; trombosit dağılım geniş̧liği MPV; ortalama trombosit hacmi, ELO; eozinofil/lenfosit oranı, BLO; bazofil/lenfosit oranı, MLO; monosit/lenfosit oranı, NLO; nötrofil/lenfosit oranı, TLO; trombosit/lenfosit oranı, Bağımsız Örneklemler için T- Testi, * Mann-Whitney U Testi

Nötrofil sayısı, lenfosit sayısı, trombosit sayısı, eozinofil sayısı ve monosit sayısı bakımdan gruplar arasında istatistiksel olarak anlamlı fark saptanırken $(\mathrm{p}<0,05)$; hemoglobin, hematokrit, eritrosit sayısı, lökosit sayısı, bazofil sayısı, MCV, MPV, RDW ve PDW değerleri bakımından istatistiksel olarak anlamlı fark saptanmadı $(\mathrm{p}>0,05)$. Grup 2 ile karşılaştırıldığında, sepsisli yenidoğanların nötrofil sayısı $(7,24 \pm 4,26$ vs $5,13 \pm 4,4$, $p<0,001)$ istatistiksel olarak anlamlı yüksekken; lenfosit sayısı $(3,80 \pm 1,59$ vs $4,81 \pm 1,77, p=0,001)$, trombosit sayısı $\quad(235,73 \pm 144,63 \quad$ vs $303,23 \pm 115,62, \quad p<0,001)$, eozinofil sayıs $(0,28 \pm 0,25$ vs $0,43 \pm 0,23, p<0,001)$ ve monosit sayısı $(1,15 \pm 0,71$ vs $1,49 \pm 0,64, p=0,005)$ istatistiksel olarak anlamlı düşük idi (Tablo 2).

Tam kan sayımına dayalı skorlar incelendiğinde NLO ve ELO değerleri bakımından gruplar arasında istatistiksel olarak anlamlı fark saptanirken $(p<0,05) ;$ BLO, MLO ve TLO değerleri bakımından istatistiksel olarak anlamlı fark saptanmadı ( $p>0,05)$. Grup 2 (sağlıklı yenidoğanlar) ile karşılaştırıldığında, 
sepsisli yenidoğanların NLO $(2,19 \pm 1,39$ vs $1,44 \pm 1,07, \mathrm{p}<0,001)$ değeri istatistiksel olarak anlamlı yüksekken; ELO $\quad(0,08 \pm 0,07$ vs $0,09 \pm 0,05, p=0,007)$ değeri istatistiksel olarak anlamlı düşük idi (Tablo 2).

Tablo 3: CRP değeri ve laboratuvar parametreleri arasındaki ilişkiyi gösteren korelasyon katsayıları ve istatistiksel değerlendirmeleri.

\begin{tabular}{|c|c|c|}
\hline & \multicolumn{2}{|c|}{ CRP } \\
\hline & $\mathrm{r}$ & $\mathrm{p}$ \\
\hline NLO & 0,266 & 0,002 \\
\hline ELO & $-0,180$ & 0,037 \\
\hline Nötrofil (10L) & 0,158 & 0,068 \\
\hline Lenfosit $\left(10^{9} / \mathrm{L}\right)$ & $-0,253$ & 0,003 \\
\hline Trombosit (109/L) & $-0,244$ & 0,004 \\
\hline Eozinofil $\left(10^{9} / \mathrm{L}\right)$ & $-0,290$ & 0,001 \\
\hline Monosit $\left(10^{9} / \mathrm{L}\right)$ & $-0,271$ & 0,001 \\
\hline
\end{tabular}

CRP değeri sepsisli yenidoğanlarda 51,3 $\pm 60,4$, sağlıklı yenidoğanlarda ise $3,16 \pm 0,47$ olarak saptandı. İki grup arasındaki fark istatistiksel olarak anlaml idi $(\mathrm{p}<0,001$, Tablo 2). CRP değeri ile NLO (r=0,266, $p=0,002)$ değeri arasında istatistiksel olarak anlamlı pozitif korelasyon; CRP değeri ile ELO ( $\mathrm{r}=-0,180$, $\mathrm{p}=0,037)$, lenfosit sayısı ( $\mathrm{r}=-0,253, \mathrm{p}=0,003)$, trombosit sayısı $(r=-0,244, p=0,004)$, eozinofil sayısı $(r=-0,2290, p=0,001)$ ve monosit sayısı $(\mathrm{r}=-0,271, \quad \mathrm{p}=0,001)$, değerleri arasında istatistiksel olarak anlaml negatif korelasyon tespit edildi (Tablo 3).

ROC analizlerinde yenidoğan sepsisi tanısı koymada; CRP'nin 6,09 mg/L eşit değerinde \%88,57 duyarlılı, \%100 özgüllük (AUC:0,964, $\mathrm{p}<0,001$ ), NLO'nun 1,01 eşit değerinde \%78,57 duyarlılık, \%63,08 özgüllük (AUC:0,727, $\mathrm{p}<0,001)$, ELO'nun 0,079 eşit değerinde $\% 64,29$ duyarlılık, \%56,92 özgüllük (AUC:0,634, p=0,007), nötrofil sayısının 4,66 eşit değerinde \%68,57 duyarlılık, \%61,54 özgüllük (AUC:0,683, $\quad \mathrm{p}<0,001)$, lenfosit sayısının 4,33 eșit değerinde $\% 65,71$ duyarlılık, $\%$ 60,00 özgüllük (AUC:0,668, $\mathrm{p}=0,001$ ), trombosit sayısının 259,00 eşit değerinde $\% 62,86$ duyarlılık, \%58,46 özgüllük (AUC:0,659, p=0,001), eozinofil sayısının 0,27 eşit değerinde \%61,42 duyarlılık, \%69,23 özgüllük (AUC:0,708, p<0,001) ve monosit sayısının 1,33 eșit değerinde \%62,86 duyarlılık, $\% 56,92$ özgüllük (AUC:0,647, $\quad \mathrm{p}=0,003$ ) gösterdiği bulunmuştur (Tablo 4).

Tablo 4: CRP ve tam kan sayımına dayalı skorların ROC analizi.

\begin{tabular}{|l|c|c|c|c|c|c|c|}
\hline & AUC & SE & $95 \%$ CI & $\begin{array}{c}\text { Eşit } \\
\text { değer }\end{array}$ & $\begin{array}{c}\text { Duyarlılı } \\
(\%)\end{array}$ & Özgüllük & (\%) \\
\hline $\begin{array}{l}\text { CRP } \\
\text { (mg/L) }\end{array}$ & 0,964 & 0,018 & $\begin{array}{c}0,928- \\
1,000\end{array}$ & 6,09 & 88,57 & 100,00 & $<0,001$ \\
\hline NLO & 0,727 & 0,044 & $\begin{array}{c}0,641- \\
0,814\end{array}$ & 1,01 & 78,57 & 63,08 & $<0,001$ \\
\hline ELO & 0,634 & 0,049 & $\begin{array}{c}0,539- \\
0,730\end{array}$ & 0,079 & 64,29 & 56,92 & 0,007 \\
\hline $\begin{array}{l}\text { Nötrofil } \\
\left(10^{9} / \mathrm{L}\right)\end{array}$ & 0,683 & 0,046 & $\begin{array}{c}0,592- \\
0,774\end{array}$ & 4,66 & 68,57 & 61,54 & $<0,001$ \\
\hline $\begin{array}{l}\text { Lenfosit } \\
\left(10^{9} / \mathrm{L}\right)\end{array}$ & 0,668 & 0,046 & $\begin{array}{c}0,577- \\
0,759\end{array}$ & 4,33 & 65,71 & 60,00 & 0,001 \\
\hline $\begin{array}{l}\text { Trombosit } \\
\left(10^{9} / \mathrm{L}\right)\end{array}$ & 0,659 & 0,047 & $\begin{array}{c}0,568- \\
0,751\end{array}$ & 259,00 & 62,86 & 58,46 & 0,001 \\
\hline $\begin{array}{l}\text { Eozinofil } \\
\left(10^{9} / \mathrm{L}\right)\end{array}$ & 0,708 & 0,045 & $\begin{array}{c}0,620- \\
0,796\end{array}$ & 0,27 & 61,42 & 69,23 & $<0,001$ \\
\hline $\begin{array}{l}\text { Monosit } \\
\left(10^{9} / \mathrm{L}\right)\end{array}$ & 0,647 & 0,047 & $\begin{array}{c}0,555- \\
0,740\end{array}$ & 1,33 & 62,86 & 56,92 & 0,003 \\
\hline
\end{tabular}

CRP; C-Reaktif Protein, NLO; nötrofil/lenfosit oranı, ELO; eozinofil/lenfosit oranı

\section{TARTIŞMA}

Yenidoğan sepsisinde tam kan sayımı parametrelerini ve tam kan sayımına dayalı skorları değerlendirdiğimiz çalışmamızın sonucunda; yenidoğan sepsisli hastalarda NLO ve nötrofil sayısının yüksek, ELO, lenfosit, trombosit, eozinofil ve monosit saylarının ise düşük olduğunu ve ayrıca NLO ile CRP değeri arasında pozitif, ELO, lenfosit, trombosit, eozinofil ve monosit sayısı ile CRP değeri arasında ise negatif korelasyon tespit ettik. Ek olarak, ROC curve analizi sonuçlarına göre CRP, NLO, ELO, nötrofil, lenfosit, trombosit, eozinofil ve monosit sayılarının yenidoğan sepsisi tanısı için anlamlı parametreler olduğunu saptadık.

Yenidoğan sepsisi, özellikle erken doğmuş bebeklerde morbidite ve mortalitenin önemli 
bir nedenidir. Bu nedenle erken tanı son derece önemlidir ancak neonatal sepsisin erken ve kesin tanısı, spesifik olmayan belirti ve semptomların yanı sira kesin tanıda altın standart olan kan kültürü sonuçlarının en erken 48-72 saatte alınması nedeniyle zordur. Ayrıca tanı için kullanılabilecek \%100 duyarlılık ve özgüllüğe sahip güvenilir ve uygun maliyetli bir laboratuvar yöntemi henüz keşfedilmemiştir. Günümüzde tanı için yaygın olarak kullanılan biyo-belirteçler CRP ve PCT'dir ancak her ikisinin de duyarlılık ve özgüllükleri tek başına tanı için yeterli değildir, ayrıca her ikisi de farklı çalışmalarda çeşitli duyarlılık, özgüllük, PPV ve NPV göstermiştir'6. Son zamanlarda yayınlanan 37 çalışmanın değerlendirildiği bir meta analizde CRP'nin yenidoğan sepsisi tanısı için düşük duyarlılık (\%30-80) ancak yüksek özgüllük (\%83-100) gösterdiği bildirilmiştir ${ }^{16}$.

Tam kan sayımı uygun maliyetli basit bir yöntemdir ve pek çok hastalık için tanı ve takip parametrelerini içerir. Günümüzde, tam kan sayımından elde edilen lökosit sayısı, trombosit sayısı ve nötrofil sayısı yenidoğan sepsisi laboratuvar tanı kriterleri arasında yer almaktadır ${ }^{8}$. Son yıllarda, yenidoğan sepsisinin tanısı için kolay erişilebilen ve uygun maliyetli olan tam kan sayımı parametreleri yeniden gözden geçirilmekte ve tam kan sayımı parametrelerine dayanan skorlar araştırılmaktadır1,9-14. Ancak tam kan sayımı parametrelerinin hepsini ve bu parametrelere dayalı tüm skorları inceleyen herhangi bir çalışmaya rastlanmadı. Bu çalışmanın tüm bu parametreleri bir arada inceleyen ilk çalışma olduğunu düşünüyoruz.

İnflamatuar olaylarda nötrofil sayısının arttığı lenfosit sayısının ise azaldığı bilinmektedir ${ }^{17}$. NLO nötrofil ve lenfosit sayılarını bir arada içeren bir parametre olduğundan inflamasyonu belirlemede daha etkin bir parametre olabileceği düşünülmüş ve son yıllarda yapılan çalışmalarda NLO diğer pek çok inflamatuar hastalıkta ${ }^{17,18}$ olduğu gibi yenidoğan sepsisi tanısı için de inflamatuar bir biyobelirteç olarak değerlendirilmiștir ${ }^{1,11,13,14}$. Omran ve arkadaşlarının 35 sepsisli yenidoğan 9'u $(\% 25,7)$ erken başlangıçlı yenidoğan sepsisi ve 26 'sı $(\% 74,3)$ geç başlangıçlı yenidoğan sepsisi) ve 35 sağlıklı kontrol dahil ederek yaptığı çalışmada NLO değerinin sepsisli yenidoğanlarda kontrollere göre yüksek olduğu $(2,9 \pm 1,7$ vs $1,6 \pm 0,4, p<0,001)$ ve yenidoğan sepsisini öngörmede NLO değerinin 2,7'lik eşit değerde, \%80,0'lık duyarlılığa ve \%57,1'lik özgüllüğe sahip olduğu bildirilmiștir ${ }^{1}$. Ayrıca bu çalışmada yenidoğan sepsisi tanısı için TLO'nun anlamsız bir parametre olduğu gösterilmiştir ${ }^{1}$. Can ve arkadaşları 122 yenidoğanı (78'i erken başlangıçlı yenidoğan sepsisi ve 44'ü sağlıklı kontrol) dahil ettikleri çalışmalarında NLO ve TLO'nun yenidoğan sepsisinde yardımcı tanısal parametreler olarak kullanılabileceklerini söylemişlerdir ${ }^{13}$. Alkan ve arkadaşları 57 kültürle kanıtlanmış ve 75 şüpheli toplam 127 geç başlangıçlı yenidoğan sepsisli olguyu dahil ettikleri çalışmalarında NLO'nun kültür pozitif sepsisli olgularda şüpheli sepsisli olgulara göre daha yüksek olduğunu ve NLO'nun kültür pozitif yenidoğan sepsisini öngörmede CRP'den daha iyi bir parametre olduğunu bildirmişlerdir ${ }^{14}$. Wilar ise 30 sağlıklı ve 90 erken başlangıçlı yenidoğan sepsisli olguyu dahil ettiği çalışmasında erken başlangıçlı yenidoğan sepsisi grubunda NLO değerinin sağlıklı kontrollere göre yüksek olduğunu $(2,82 \pm 2,29$ vs $0,82 \pm 0,32 p<0,001)$ ve erken başlangıçlı yenidoğan sepsisi tanısı koymada biyo-belirteç olarak 1,245 eşit değerinde yüksek duyarlılık $(\% 83,3)$ ve özgüllük $(\% 93,3)$ değerine sahip olduğunu bildirmiştiri1. Literatürle uyumlu olarak biz de çalışmamızda yenidoğan sepsisli olgularda nötrofil sayısının yükseldiğini $(7,24 \pm 4,26$ vs $5,13 \pm 4,4, p<0,001)$, lenfosit sayısının azaldığını $(3,80 \pm 1,59$ vs $4,81 \pm 1,77, p=0,001)$ ve bu durumlara bağlı olarak NLO'nun yükseldiğini $(2,19 \pm 1,39$ vs $1,44 \pm 1,07, p<0,001$ ) bulduk. Dahası, yenidoğan sepsisi tanısinda NLO'nun tanisal performansının (NLO'nun 1,01 eşit değerinin 
üstünde olması $\% 78,57$ duyarlılık, $\% 63,08$ özgüllük (AUC:0,727, p<0,001) gösteriyordu) diğer tüm kan sayımı parametrelerinden üstün olduğunu tespit ettik. Ayrıca CRP ile NLO arasinda pozitif $(\mathrm{r}=0,266, \mathrm{p}=0,002)$, lenfosit sayısı arasında negatif $(\mathrm{r}=-0,253, \mathrm{p}=0,003)$ korelasyon tespit ettik. Literatürde yenidoğan sepsisi tanısında TLO kullanımı ile ilgili sonuçlar çelişkilidir. Yorulmaz ve arkadaşları PLO değeri açısından yenidoğan sepsisi ve kontrol grubu arasında fark olmadığını $(68,24 \pm 28,72$ vs $71,27 \pm 25,67, \quad p=0,178)$ bildirmișlerdir ${ }^{19}$. Ayrica Omran ve ark. ${ }^{1}$ yenidoğan sepsisi tanısında TLO'nun anlamsız, Can ve ark.13 ise anlaml bir parametre olduğunu belirtmiştir. Çalışmamızda yenidoğan sepsisli olgularda TLO değerinin düşük olduğunu $\quad(61,66 \pm 37,52$ vs $68,39 \pm 30,06$, $\mathrm{p}=0,182$ ) ancak aradaki bu farkın istatistiksel olarak anlamlı olmadığını ve TLO'nun yenidoğan sepsisi tanısında anlamlı bir parametre olmadığını saptadık.

Trombositopeni yenidoğan sepsisi laboratuvar tanı kriterleri arasında yer almaktadır ${ }^{8}$. Taşyurt ve arkadaşları trombosit sayısının yenidoğan sepsisli grupta kontrol grubuna göre anlamlı olarak düşük olduğunu $(191476,38 \pm 191476,38$ hücre $/ \mathrm{mm}^{3} \quad$ vs $\quad 306666,67 \pm 116998,77$ hücre $/ \mathrm{mm}^{3}, \mathrm{p}=0,004$ ) ve yenidoğan sepsisi tanısı koymada duyarlılığının \%62,5 özgüllüğünün ise $\% 45$ olduğunu bildirmişlerdir ${ }^{9}$. Biz de çalışmamızda literatürle uyumlu olarak yenidoğan sepsisinde trombosit sayısının düşük olduğunu $(235,73 \pm 144,63 x$ $109 / \mathrm{L}$ vs $303,23 \pm 115,62 \times 109 / \mathrm{L}, \mathrm{p}<0,001$ ), CRP ile negatif korelasyon gösterdiğini $(r=-0,244$, $\mathrm{p}=0,004$ ) ve yenidoğan sepsisi tanısı koymada duyarlılığının \%62,86 özgüllügünün ise $\% 58,46$ olduğunu bulduk. Yapılan çalışmalarda yenidoğan sepsisi tanısı için trombosit sayısına ek olarak MPV ve PDW değerlerine de bakılmıștır. PDW trombosit boyutuyla ilgili bir parametreyken MPV trombosit aktivasyonuyla ilgili bir parametredir. Düşük trombosit sayısı, yüksek MPV ve PDW değerlerinin yenidoğan sepsisi ile ilişkili parametreler olduğu bildirilmiştir ${ }^{20}$. Taşyurt ve arkadaşları MPV değerinin yenidoğan sepsisi grubunda yüksek olduğunu, PDW değeri açısından gruplar arasında fark olmadığını, ve sepsis tanısı koymada MPV değerinin duyarlılığının \%100 özgüllügünün ise $\quad \% 42,3 \quad$ olduğunu belirtmişlerdir ${ }^{9}$. Yorulmaz ve arkadaşları ${ }^{19}$ ise hem MPV hem de PDW değerlerinin yenidoğan sepsisi grubunda yüksek olduğunu bildirmişlerken, Can ve ark. ${ }^{13}$ MPV ve PDW değerleri açısından gruplar arasında fark olmadığını tespit etmişlerdir. Bizim çalışmamızda da MPV ve PDW değerleri yenidoğan sepsisli olgularda sağlkklı yenidoğanlara göre az da olsa yüksek bulunmuş olmasına rağmen aradaki bu fark istatistiksel olarak anlamlı değildi.

Akut inflamasyonda, kemik iliğinden olgun eozinofil yapımının ve salgilanmasının baskılanması sonucunda eozinopeni geliştiği bilinmektedir ${ }^{21}$. Gil ve arkadaşları eozinofil sayısının enfeksiyonun bir göstergesi olduğunu bildirmişler ve eozinofil sayısının $40 / \mathrm{mm}^{3}$ ün altında olmasının bakteriyel enfeksiyonların varlığıyla ilişkili olduğunu göstermişlerdir ${ }^{22}$. Abidi ve arkadaşları eozinopeninin günlük klinik uygulamada enfeksiyon belirteci olarak faydalı olabileceğini öne sürmüştür ${ }^{23}$. Son günlerde yayınlanmış olan bir çalışmada eozinopeninin erken başlangıçlı yenidoğan sepsisinin tanısal bir belirteci olarak yüksek özgüllük değerine sahip olduğu ve eozinofil sayısının 140 hücre $/ \mathrm{mm}^{3}$ eşit değerinin altında olmasının $\% 60,0$ duyarlılık ve \%90,0 özgüllük gösterdiğini bildirilmiştir ${ }^{11}$. Bu çalıșmalarla uyumlu olarak biz de çalışmamızda yenidoğan sepsisli olgularda eozinofil sayısının sağlıklı yenidoğanlara göre düşük olduğunu $(0,28 \pm 0,25$ vs $0,43 \pm 0,23, p<0,001)$ ve yenidoğan sepsisi tanısında eozinofil sayısının $0,27 \times 109 \mathrm{~L}$ eșit değerinin altında olmasının \%61,42 duyarlılık ve \%69,23 özgüllük (AUC:0,708, p<0,001) gösterdiğini bulduk. ELO düzeyinin diğer otoimmün hastalıklarda yükselmiş olmasına 
rağmen sistemik lupus erimatozusda (SLE) düştüğü bildirilmiştir ${ }^{24}$. Biz de çalışmamızda yenidoğan sepsisli olgularda sağlıklı yenidoğanlara göre ELO değerinin daha düşük olduğunu ve ELO'nun 0,079 eşit değerinin altında olmasının \%64,29 duyarlılık ve \%56,92 özgüllük (AUC:0,634, p=0,007) gösterdiğini tespit ettik.

İnflamasyon sırasında aktif monositler, endotelyal yuvarlama ve ekstravazasyon yoluyla dolaşımdan çlkarılarak dokulara geçerler ${ }^{25}$. Sepsiste/endotoksemide monosit sayısında hızlı düşüş olduğu gösterilmiştir ${ }^{26}$. Bu çalışmayla uyumlu olarak biz de çalışmamızda yenidoğan sepsisli olgularda monosit sayısının sağlıklı yenidoğanlara göre daha düşük $(1,15 \pm 0,71$ vs $1,49 \pm 0,64, p=0,005)$ olduğunu bulduk. Dahası, yenidoğan sepsisi tanısında monosit sayısının 1,33x109L eşit değerinin altında olmasının \%62,86 duyarlılık ve \%56,92 özgüllük (AUC:0,647, p=0,003) gösterdiğini tespit ettik. $\mathrm{Bu}$ çalışma yenidoğan sepsisi tanısında ELO ve monosit sayısını biyo-belirteç olarak değerlendiren ilk çalışmadır.

Sonuç olarak duyarlılık ve özgüllükleri CRP'den düşük olmasına rağmen; NLO, ELO, nötrofil, lenfosit, trombosit, eozinofil ve monosit sayıları yenidoğan sepsisi tanısına katkıda bulunan yardımcı veriler olarak kabul edilebilir. Özellikle, NLO en yüksek duyarlılık ve özgüllük ile neonatal sepsis tanısında en yararlı tam kan sayımı parametresi gibi görünmektedir.

Çıkar Çatışması: Yazarlar bu yazının hazırlanması ve yayınlanması hususunda çıkar çatışması olmadığını beyan etmişlerdir.

Finansal Destek: Çalışmamız, herhangi bir fondan maddi destek almamıştır.

Declaration of Conflicting Interests: The authors hereby declare that they have no conflict of interest.

Financial Disclosure: No financial support was received

\section{KAYNAKLAR}

1. Omran A, Maaroof A, Saleh MH, Abdelwahab A. Salivary C-reactive protein, mean platelet volume and neutrophil lymphocyte ratio as diagnostic markers for neonatal sepsis. J Pediatr (Rio J). 2018; 94: 82-7.

2. Camacho-Gonzalez A, Spearman PW, Stoll BJ. Neonatal infectious diseases: evaluation of neonatal sepsis. Pediatr Clin North Am. 2013; 60: 367-89.

3. Raimondi F, Ferrara T, Maffucci R, et all. Neonatal sepsis: a difficult diagnostic challenge. Clin Biochem. 2011; 44: 463-4.

4. Gerdes JS. Diagnosis and management of bacterial infections in the neonate. Pediatr Clin N Am. 2004; 51: 939-59.

5. Zea-Vera A and Ochoa TJ. Challenges in the diagnosis and management of neonatal sepsis. J Trop Pediatr. 2015; 61: 1-13.

6. Sharma D, Farahbakhsh N, Shastri S, Sharma P. Biomarkers for diagnosis of neonatal sepsis: a literature review. J Matern Fetal Neonatal Med. 2018; 31: 1646-59.

7. Kaya Z. Interpretation of automated blood cell counts. Dicle Med J. 2013; 40: 521-8.

8. Ognean ML, Boicean A, Șular FL, Cucerea M. Complete blood count and differential in diagnosis of early onset neonatal sepsis. Rev Romana Med Lab. 2017; 25: 101-8.

9. Taşyurt N, Olukman Ö, Çalkavur Ş, et all. Diagnostic Value of Platelet Parameters in Neonatal Sepsis. Journal of Dr. Behcet Uz Children's Hospital 2012; 2: 10-7.

10. Hanaganahalli SB, Sreeram S, Bompada M, et all. Is MPV a Predictive Marker for Neonatal Sepsis? A Pilot Study. J Pediatr Hematol Oncol. 2018; 40: 548-52.

11. Wilar R. Diagnostic value of eosinopenia and neutrophil to lymphocyte ratio on early onset neonatal sepsis. Korean J Pediatr. 2018 Oct 8. doi: 10.3345/kjp.2018.06723.

12. Ellahony DM, El-Mekkawy MS, Farag MM. A Study of Red Cell Distribution Width in Neonatal Sepsis. Pediatr Emerg Care. 2017 Oct 27. doi: 10.1097/PEC.0000000000001319.

13. Can E, Hamilcikan Ş, Can C. The Value of Neutrophil to Lymphocyte Ratio and Platelet to Lymphocyte Ratio for Detecting Early-onset Neonatal Sepsis. J Pediatr Hematol Oncol. 2018; 40: e229-32. 
14. Alkan Ozdemir S, Arun Ozer E, Ilhan O, Sutcuoglu S. Can neutrophil to lymphocyte ratio predict late-onset sepsis in preterm infants? J Clin Lab Anal. 2018; 32: e22338.

15.

https://www.ema.europa.eu/documents/report/repor t-expert-meeting-neonatal paediatric-sepsis_en.pdf

16. Hedegaard SS, Wisborg K, Hvas A-M. Diagnostic utility of biomarkers for neonatal sepsis-a systematic review. Infect Dis (Lond). 2015; 47: 117-24.

17. Kılıç E, Rezvani A, Toprak Erek A, et all. Evaluation of Neutrophil to Lymphocyte and Platelet to Lymphocyte Ratios in Rheumatoid Arthritis. Dicle Med J. 2016; 43: 241-7.

18. An I, Uçmak D. Evaluation of neutrophil-tolymphocyte ratio, platelet-to-lymphocyte ratio, mean platelet volume, and C-reactive protein in patients with psoriasis vulgaris. Dicle Med J. 2018; 45: 327-34.

19. Yorulmaz A, Yücel M, Sert S. Diagnostic value of haematological parameters in neonatal sepsis cases. Ortadogu Medical Journal 2018; 10: 252-62.

20. Choudhary RR, Makwana M, Mourya HK, Dabi J, Gulati $\mathrm{K}$. Evaluation of platelet and its indices as a marker of neonatal sepsis: a prospective case control study. Int J Contemp Pediatr. 2018; 5: 1898-1903.
21. Bass DA. Behavior of eosinophil leukocytes in acute inflammation.II. Eosinophil Dynamics during acute inflammation.J Clin Invest. 1975; 56: 870-9.

22. Gil H, Magy N, Mauny F, Dupond JL. Value of eosinopenia in inflammatory disorders: an "old" marker revisited. Rev Med Interne. 2003; 24: 431-5.

23. Abidi K, Khoudri I, Belayachi J, et all. Eosinopenia is a reliable marker of sepsis on admission to medical intensive care units. Crit Care. 2008; 12: R59.

24. Yang Z, Zhang Z, Lin F, et all. Comparisons of neutrophil-, monocyte-, eosinophil-, and basophillymphocyte ratios among various systemic autoimmune rheumatic diseases. APMIS. 2017; 125: 863-71.

25. Kamei M, Carman CV. New observations on the trafficking and diapedesis of monocytes. Curr Opin Hematol. 2010; 17: 43-52.

26. Gille-Johnson P, Smedman C, Gudmundsdotter L, et all. Circulating monocytes are not the major source of plasma cytokines in patients with sepsis. Shock. 2012; 38: 577-83. 